\title{
PENERAPAN PENCATATAN AKUNTANSI PADA USAHA KECIL MENENGAH YANG ADA DI DESA TARA-TARA
}

\author{
Anita Nisa Kambey \\ Fakultas Ekonomi, Universitas Negeri Manado \\ anitakambey@gmail.com
}

\begin{abstract}
Abstrak
Usaha kecil dan menengah pun hingga saat ini masih dianggap sebagai penyelemat perekonomian Indonesia karena menyediakan alternative kegiatan usaha produktif dan alternative penyaluran kredit. Selain itu, tidak adanya pelaporan akuntansi yang benar menghambat UMKM untuk memperoleh penyaluran bantuan kredit dari pemerintah maupun investor luar negeri.Hal ini pulalah yang dialami oleh kelompok peternak yang ada di desa tara-tara. Persepsi yang salah mengenai akuntansi membuat UMKM sulit berkembang. Namun dalam kegiatan bisnis ada kalanya mengalami kendala misalnya kredit macet, barang hilang ataupun piutang yang tidak dapat ditagih.Bagi pelaku UMKM yang tidak memiliki wawasan akuntansi, hal ini dapat mempersulit kegiatan usahanya.Oleh karena itu akuntansi sangat membantu para pelaku UMKM yang ingin mengatasi masalah keuangan dan mengembangkan usahanya. Artikel ini membahas bagaimana penerapan pencatatan akuntansi bagi pelaku UMKM. Hasil yang diperoleh dari kegiatan ini antara lain 1) kelompok peternak Sejahtera memahami pentingnya pencatatan akuntansi hingga laporan keuangan, 2) tersedianya laporan keuangan yang dapat membantu mitra dalam mengembangkan usahanya.
\end{abstract}

\section{Kata Kunci: Pencatatan Akuntansi, UMKM}

\section{PENDAHULUAN}

Usaha Kecil dan menengah di Indonesia memiliki peranan yang penting dalam perekonomian baik ditinjau dari segi jumlah usaha maupun dari segi penciptaan lapangan kerja.Usaha kecil dan menengah pun hingga saat ini masih dianggap sebagai penyelemat perekonomian Indonesia karena menyediakan alternative kegiatan usaha produktif dan alternative penyaluran kredit.

Mengingat begitu besarnya peranan usaha kecil dan menengah bagi perekonomian Indonesia maka pemerintah mengaturnya dalam undang-undang no.20 tahun 2008 tentang Usaha kecil menengah sebagai berikut: a). Memiliki kekayaan bersih lebih dari Rp. 50.000 .000 sampai paling banyak Rp.500.000.000 tidak termasuk tanah dan bangunan tempat usaha.b). Memiliki hasil penjualan tahunan lebih dari Rp. 300.000 .000 sampai dengan paling banyak $\mathrm{Rp}$. 2.500.000.000 c). Milik Warga Negara Indonesia d) Berdiri sendiri, bukan merupakan anak perusahaan atau cabang perusahaan yang dimiliki, dikuasai atau berafiliasi baik langsung maupun tidak langsung dengan usaha menengah atau usaha bersama e) Berbentuk usaha perseorangan, badan usaha yang tidak berbadan hukum, badan usaha yang berbadan hukum termasuk koperasi.

Namun muncul permasalahan yang baru dalam usaha kecil dan menengah yaitu para pelaku Usaha Kecil dan Menengah belum memahami arti penting akuntansi yang terimplementasi dalam laporan keuangan.Akibat tidak adanya sistem pelaporan akuntansi banyak pelaku usaha UKM yang gulung tikar ketika mengalami gagal panen atau gagal produk.Selain itu, tidak adanya pelaporan akuntansi yang benar menghambat UKM untuk memperoleh penyaluran bantuan kredit dari pemerintah maupun investor luar negeri.Hal ini pulalah yang dialami oleh kelompok peternak yang ada di desa tara-tara.

Persepsi yang salah mengenai akuntansi membuat UMK sulit berkembang.Bagi pelaku UKM menggunakan jasa akuntans adalah pengeluaran biaya yang tidak penting dan tidak berguna.Tidak hanya masalah biaya saja, waktu juga menjadi masalah karena mereka beranggapan bahwa pekerjaan akuntansi merupakan pekerjaan administrative dan tidak menghasilkan keuntungan apapun. 
Pengetahuan akuntansi yang minim seperti penerimaan dan pemasukan masih dianggap relevan oleh sebagian pelaku UKM.Namun dalam kegiatan bisnis ada kalanya mengalami kendala misalnya kredit macet, barang hilang ataupun piutang yang tidak dapat ditagih.Bagi pelaku UKM yang tidak memiliki wawasan akuntansi, hal ini dapat mempersulit kegiatan usahanya.Oleh karena itu akuntansi sangat membantu para pelaku UKM yang ingin mengatasi masalah keuangan dan mengembangkan usahanya.

\section{METODE}

Mekanisme pelaksanaan ipteks ini dilaksanakan menggunakan metode desain riset yang meliputi preliminary design, teaching experiment, dan retrospective analysis yang dilaksanakan pada bulan maret s/d juli 2017 dengan subjek yaitu kelompok peternak sejahtera

Teknik Pengumpulan data menggunakan observasi, dokumentasi, tes, dan wawancara. Sedangkan teknik analisis menggunakan analisis dokumen, analisis tes, analisis observasi, serta analisis wawancara.

\section{HASIL \& PEMBAHASAN}

Pelaksanaan kegiatan IbM Kelompok peternak Sejahtera yang ada di desa tara-tara didahului dengan persiapan yang dilakukan berkoordinasi dengan kepala kelurahan desa tara-tara. Hasilnya disepakati bahwa pelaksanaan pengabdian dilaksanakan pada kelompok peternak "sejahtera".

Selanjutnya dilaksanakan workshop kepada kelompok peternak "sejahtera" yang dihadiri oleh enam orang anggota kelompok yaitu: bapak Hendy Rompas mewakili pihak perbankan, bapak elly kaunang, bapak frans, ibu meida tamboto, Ibu Agnes Sambur, Ibu Ut Pogalin dan Ibu Kiki.

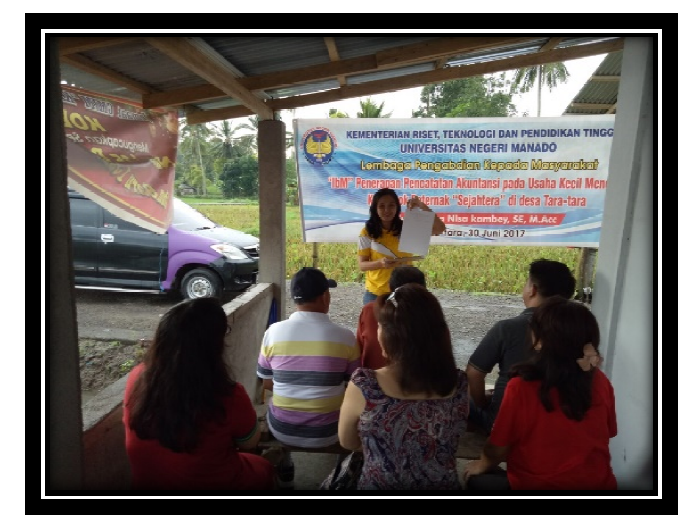

Gambar 1 Suasana pemberian Materi Pencatatan Akuntansi pada pelaku UMKM Kelompok Sejahtera

Para peserta workshop menerima materi mengenai pencatatan akuntansi yang dimulai dari menganalisa bukti bukti pendukung, kemudian mencatatkan dalam jurnal umum yang terdiri dari penerimaan dan pengeluaran selanjutnya bentuk-bentuk laporan keuangan sederhana yang mudah untuk dipraktekkan dalam kegiatan yang berkaitan dengan UMKM.

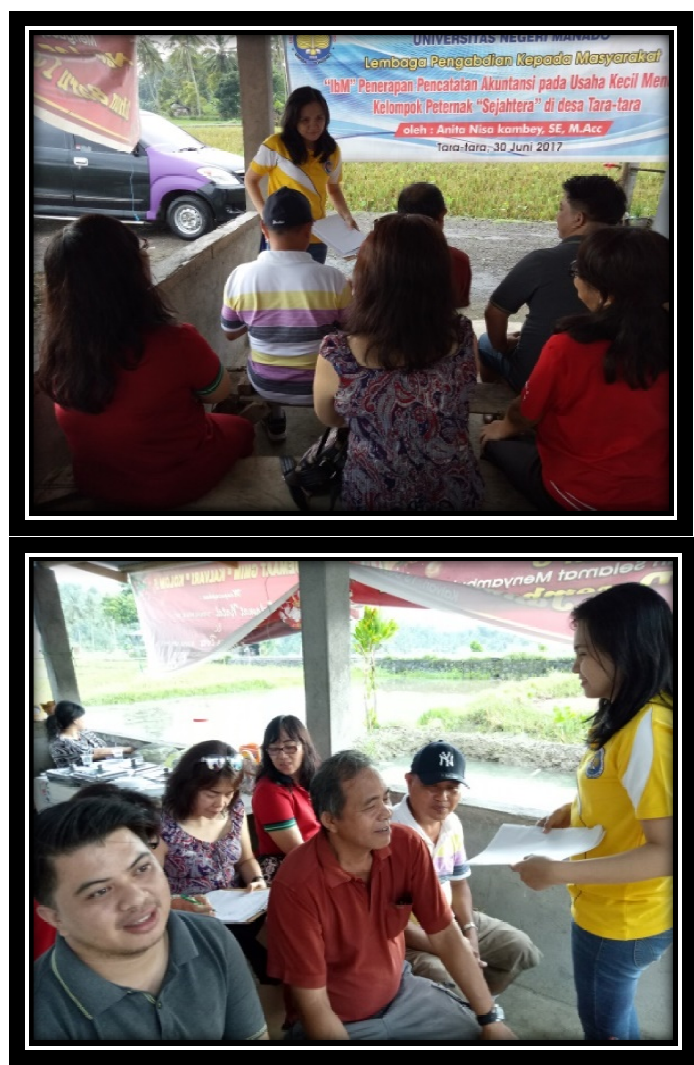

Gambar 2. Suasana Pendampingan Materi oleh Tim Pengabdi

Melakukan pendampingan kepada setiap anggota kelompok dalam melakukan kegiatan

$$
\mathrm{P} \text { a g e } 24 \mid 75
$$


akuntansi yang dimulai dari menganalisis bukti-bukti transaksi atau bukti-bukti penerimaan dan pengeluaran kemudian mencatatkan dalam buku jurnal atau buku harian yang akan digunakan dalam pembuatan laporan keuangan. Laporan keuangan yang dimaksud adalah laporan keuangan dalam bentuk sederhana.
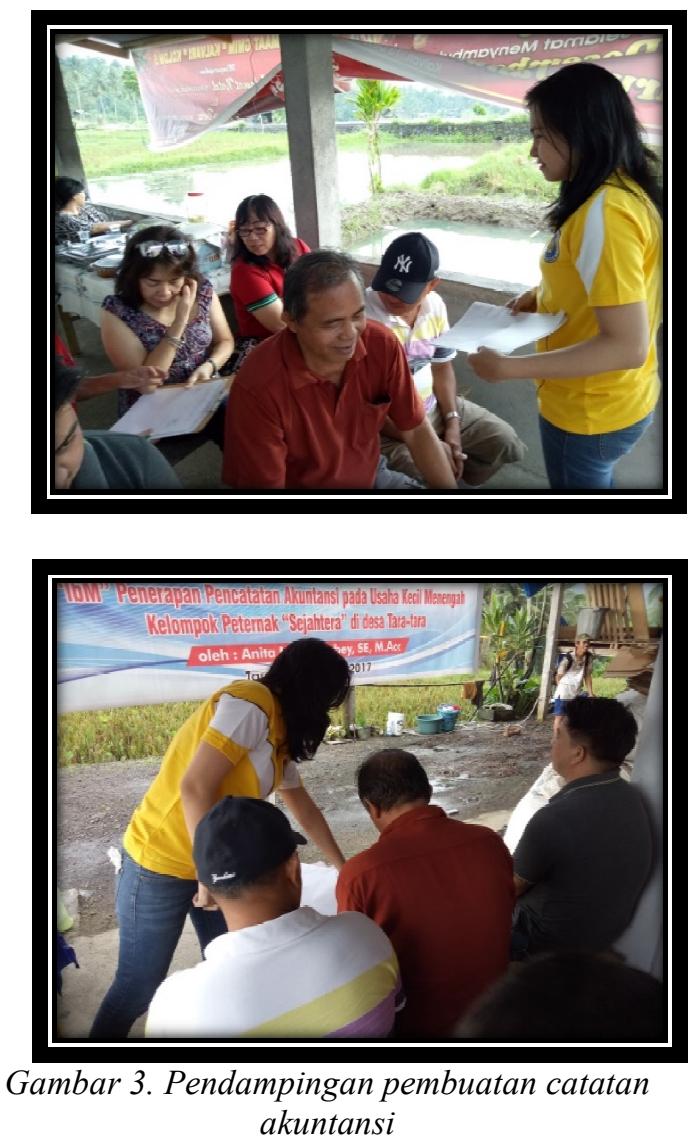

Penerapan akuntansi pada usaha kecil menengah sangat penting untuk membantu pengusaha kecil mengendalikan modal usaha dan modal kerja secara seksama.Bagi para wirausahawan tentu sangat dimengerti bahwa informasi keuangan atau akuntansi yang handal dan tepat waktu dapat menjadi faktor penentu penting untuk mengambil keputusan yang berkaitan dengan bisnis yang ditekuninya. Hal ini termasuk menentukan strategi untuk meraih tujuan dan mempertahankan laju bisnis dengan beroperasi secara efisien. Yang dimaksud dengan informasi keuangan adalah catatan-catatang tentang rekap penjualan, daftar piutang, daftar hutang, jurnal dan buku besar, juga data persediaan. Laporan-laporan tersebut seharusnya tercantum pada laporan keuangan yang terdiri dari arus kas, neraca, juga laporan laba rugi.

Laporan keuangan ini dapat menjadi gambaran kondisi finansial perusahaan bahkan pada perusahaan berskala kecil dan menengah. Laporan keuangan idealnya disusun secara standar sesuai denga prinsip-prinsip akuntansi dengan bahasa yang dipahami oleh semua pelaku usaha. Dengan demikian laporan tersebut dapat menjadi dasar pertimbangan bagi

Pengambilan keputusan untuk pengajuan kredit, tawaran kerjasama,dan sbeagainya. Seperti yang sudah banyak terjadi, proses merintis pelaporan keuangan atau pembukuan yang baik bukanlah hal yang mudah dilakukan oleh semua orang karena diperlukan prinsipprinsip pembukuan dan sistem informasi yang diperlukan oleh perusahaan.

Itulah sebabnya para pengusaha menengah dan kecil enggan menerapkan sistem akuntansi standar apalagi bila dibutuhkan perangkat mahal atau harus mempekerjakan staf. Jika saat ini usaha yang ditekuni masih berskala micro, mungkin buku kas sudah cukup menjadi sistem informasi yang memadai, tetapi bila usaha tersebut semakin berkembang sistem pembukuannya pun harus turut berkembang. Misalnya pada perusahaan manufaktur sistem yang selayaknya harus semakin berkembang adalah sistem pergudangan dan penjualan atau pembelian bahan baku.

Kegiatan "IbM penerapan pencatatan akuntansi pada usaha kecil menengah pada kelompok peternak yanga ada di desa tara-tara berlangsung baik Hal ini Nampak dari ketercapaian target luaran yang diharapkan dari kegiatan ini.

Pertama, anggota kelompok mampu membuat pencatatan akuntansi hingga laporan keuangan. Anggota kelpmpok mampu untuk membedakan dokumen -dokumen pendukung antara lain bukti penerimaan kas dan bukti pengeluaran kas. Berdasarkan panduan dan pendampingan tim pengabdi kegiatan ini mennghasilkan laporan keuangan berdasarkan PSAK ETAP 
Kedua, anggota mampu membuat pencatatan hingga laporan keuangan tanpa memerlukan lagi pendampingan dari tim pengabdi.

Proses pelaksanaan IbM ini tidak lepas dari beberapa kendala yang dihadapi adalah anggota kelompok memiliki latar belakang pendidikan yang berbeda-beda sehingga tim pengabdi mengalami kesulitan dalam

\section{PENUTUP}

\section{Kesimpulan}

Simpulan yang dapat ditarik dari pelaksanaan IbM penerapan pencatatan akuntansi pada usaha kecil menengah pada kelompok peternak sejahtera yang ada di desa tara-tara adalah sebagai berikut: A). Anggota Kelompok telah memahami arti pentingnya pencatatan akuntansi pada pengusaha kecil dan menengah.B) Telah tersedianya format pemcatatan akuntansi dan laporan keuangan sehingga memudahkan dalam pembuatan laporan

\section{Saran}

Berdasarkan hasil pelaksanaan kegiatan maka disarankan: Anggota hendaknya melakukan pencatatan akuntansi secara terus menerus agar terbiasa dalam membuat laporan akuntansi yang sesuai dengan PSAK ETAP.

\section{UCAPAN TERIMA KASIH}

Saya mengucapkan terima kasih kepada rektor universitas negeri manado melalui lembaga penelitian dan pengabdian kepada masyarakat yang telah mendanai kegiatan ini lewat anggaran PNBP Universitas Negeri Manado tahun 2017

\section{DAFTAR PUSTAKA}

Benjamin, W.P., (1990). Laporan Keuangan (Ikhtisar Akuntansi) Perusahaan Kecil, Dalam, Dalam Prosiding, Seminar Akuntan Nasional, Surabaya.

Burke, J.F., (1997). Report on Standards Overload, CPA Journal, 66(3), p11.

Holmes, S. (1986). The role of practising accountants, accounting information and small business owner/manager. Australia, 259-284.

Holmes, S., \& Nicholls, D. (1988). An analysis of the use of accounting information by Australian small business. Journal of Small Business Management, 26 (2), 57 - 69. mengarahkan anggota kelompok dalam menyusun laporan keuangan. Untuk itu diperlukan pendampingan berkelanjutan agar anggota kelompok terbiasa dalam membuat laporan keuangan. Terlepas dari kendala yang disebutkan di atas, namun secara keseluruhan pelaksanaan IbM berjalan dengan baik. Karena mendapatkan respon dan atusiasme yang tinggi.

Holmes, S., \& Nicholls, D. (1989). Modeling the accounting information requirements of small businesses. Accounting and Business Research, 19 (74), 143-150.

Knutson, D.L., \& Wichmann, Jr, H., (1985). The Issue of Differential Accounting Treatment For American Small Businesses, Management Forum, Vol. 11 Sept.

Muntoro, R. K. 1990, Praktek Akuntansi Keuangan, Dalam Prosiding, Seminar Akuntan Nasional, Surabaya.

Nair, R.D, Reittenberg, dan Larry, E., (1983). Privately Held Businesses: Is There a Standards Overload?,Journal of Accountan, New York.

Nayla, Akifa, P. 2014. Komplet Akuntansi Untuk UKM dan Waralaba. Jakarta: Laksana.

Raharjo, M. D., \& Ali, F. (1993). Faktorfaktor keuangan yang mempengaruhi usaha kecil dan menengah di Indonesia, Dalam K. James \& N. Akrasanee, Aspek-aspek finansial usaha kecil dan menengah; Studi kasus Asean, (pp. 16-50). Jakarta: LP3ES. 